\title{
Comparative Analysis of Prepaid Payment Before COVID 19 and Now: A Case of India
}

\author{
Sunil Kumar, Jyoti Sharma
}

\begin{abstract}
Purpose -In India, RBI has advocated the customers to use prepaid payment instruments for contactless transactions due to COVID-19 pandemic. But there are some sectors such as, travel, cinemas, restaurants, entertainment etc. are directly hit by this and pulled the usage of prepaid payments. Whereas, grocery stores, online shopping, e-learning, online recharges, Ed Techs and utility bills etc., are augmenting the volume of prepaid payments. In nutshell, it seems critical to evaluate the actual volume and value of prepaid payments. Thus, this study has made an attempt to comparatively analyse the prepaid payments volume before COVID-19 and now. Design/methodology/approach Data for the study has been collected from secondary sources namely, Global Payment Report, RBI Report, Niti Aayog Report, Payment Method Report, Deloitte Report, The Infosys Report and from various $e$-resources. The change in trend has been done by using trend analysis where change in percentage in the volume and value of prepaid payment instruments have been calculated by using formula:
\end{abstract}

$$
\frac{\text { Current Year - Base Year }}{\text { Current Year }} \times 100
$$
was 89 percent increase in the total volume and 97 percent increase in the value of PPI transactions from demonetisation period (2016-17) to now (during COVID 19 pandemic 2020) which will be further estimated to be mounting over the end of the year 2020. Among the different instruments, wallets are reported highest usage through interoperability with UPI followed by prepaid cards and others. Research limitations Data has been collected only from the secondary sources.Other factors like share occupied by each instrument, market growth, access and availability are still ignored. Originality/value - The paper compares the volume and value of prepaid paymentsbefore COVID- 19 and now.

Keywords: Prepaid Payments, Digital Payments, Demonetisation, System Payment Instruments, Indian Economy

\section{INTRODUCTION}

The knowledge-based economy, extreme global competition and outburst of information technology are persistently reshaping the world's business environment. Technology is vibrantly and robustly changing the nature of products \& services and facilitating more efficient \& customised services to customers by increasing the potential of business. It has not only facilitated global reach of goods \& services but made them available at domestic level. Technology advances a budge towards the exchange of electronic information rather than the paper based deliverance of documents which alter the working culture of the business organisations. Since,

Revised Manuscript Received on September 13, 2020.

* Correspondence Author

Sunil Kumar, Alliance School of Business, Alliance University, Bengaluru India. Email: drsunilkumar.au@gmail.com,

Jyoti Sharma, Govt. Degree College, Udhampur, J\&K, India. Email: jyotisharmanm@gmail.com

(c) The Authors. Published by Blue Eyes Intelligence Engineering and Sciences Publication (BEIESP). This is an open access article under the CC BY-NC-ND license (http://creativecommons.org/licenses/by-nc-nd/4.0/)
Finding - Findings revealed that after demonetisations there

the introduction of Payment and Settlement System Act 2007, RBI has worked constantly towards generating a digital (i.e. electronic) payment system to increase the competence of cash less economy. Along with the debit cards, credit cards and net banking, RBI has encouraged innovative kind of payment methods known as prepaid payments. The usage of prepaid payments has grown swiftly which reduced paper-based payments. These payments permit buyers to transmit funds electronically without rapport with financial institutions for the products and services which are access electronically when bought by recipients (Chakravorti \&Lubasi, 2006). Prepaid payments facilitates the purchase of goods and services against the worth already stored in the prepaid instruments (PPI) namely, mobile wallets, smart cards, magnetic strip cards, payment vouchers and online \& mobile accounts etc. These instruments were widely accepted in many developed countries like USA and European countries and after demonetisation the Government of India (GOI) along with the joint efforts of the Reserve Bank of India (RBI) have pioneered prepaid payments. Thus, India's potential to embrace innovative payment patterns leads to rebooting the economy in the normal way and increasing the growth trajectories. Despite the significant growth in innovative payment system, the spread of novel corona virus pandemic has challenged the global economy including India. India akin to many other countries has taken major steps i.e, lockdown, social distancing, shut down of transport \& public places and restriction on movement of entire population. Significantly, it leads to economic disturbance, massive decline in business activity for businesses both large and small and is also impacting the volume and value of innovative payment formation.

\section{CONCEPTUAL ANALYSIS AND DEVELOPMENT OF PREPAID PAYMENTS AND INSTRUMENTS}

The Government of India has intended to alter Indian economy into a digitally empowered and knowledge based economy. Digitalisation is a catalyst which distorts the nation into cash less economy and ensures that all government services are evenly availed by each and every household (Chaubey \& Kumar, 2017). Thus, RBI along with government and various agencies creates an environment conducive for the development of digital payments and provides round the clock access to customers across the nation. Slozko \& Pello (2015) stated that e-payment is an imperative system which is used by individual and organisations over the internet for making safe and convenient payments.

Published By:

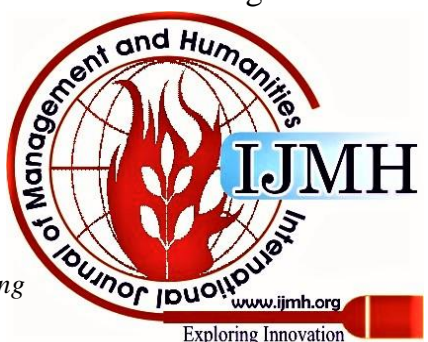


It endow the individuals with disbursement of their funds for the payment of fees, fines, duties, penalties, taxes and purchases from any peculiar sites at any time of the 365 days of the year (Kour \& Pathak, 2015). However, Roy \& Sinha (2014) found that E payment system has grown in India, but 90 percent of people still relied on cash which declines its usage. He further suggested there should be more innovative payment measures which viaduct the rigorous disparity between digital "haves" and digital "havenots"to generate an extensive and enduring developmental impact. The government initiative of Digital India in the year 2015 has increased the mobile phone and internet usage among the people which leads to boost up the digital payment system in the country (Bezhovski, 2018). Sarkar (2017) analysed that along with traditional banking products like debit cards, credit cards and net banking, RBI has promoted a relatively newer kind of payment known as prepaid payment. Pre-paid payment is that payment which is being paid in advance against the purchase of goods and services through its instruments which already have stored their worth (Shaikh et al., 2017). The value hoard in these instruments is consequent to the worth compensated by the holders in terms of cash, credit cards and debit to a bank account. The Prepaid payment instruments which are also known as prepaid cards or stored value cards were firstly appeared in USA as paper gift cards/certificates in the year 1970. Afterwards US in 1980 used it at some specific merchant locations (Specifically telecom sector) then US in 1990 in retail stores. Further, many other developed nations like Asia and Australia also adopted the same (Dennies, 2004). In India, in the early of 1990s' the RBI has forefront for the technological advancement and thus create a DPSS system (Department of Payment and Settlement System) to facilitate adoption of technology (Shah, 2017). In the year 2007, the Indian Parliament passed the Payment and Settlement Systems Act to shift towards cashless economy. Further, in the year 2008 the Reserve Bank of India (RBI) established the National Payments Corporation of India (NPCI) for standardising and articulating the multifaceted retail payment systems to make transactions simple and economical. However, demonetisation in the year 2016 has made huge transformation in digital payments system which furnishes more transparency in transactions and empowers the country's economy (Deloitte Report, 2018). Inspite of this some other key actions including spreading of digital payments infrastructure at merchant establishments and rural areas, enticement of digital payments at toll plaza's, insurance gateway, fuel pumps etc., launch of Bharat QR (Quick Response) codes and relaxation in the PPI norms laid the foundations for growth. As per INFOSYS Report (2018) prepaid payments helps to meet the varied needs of the various segments namely, customer segment, industry \& payroll processing, government segment for disbursing benefits among all, student's group, health care reimbursement, travelling expenditures, insurance sector and employee incentive processing through prepaid instruments. The pre paid instruments are issued in the form of mobile wallets or online wallets, smart cards, paper vouchers, internet or online accounts, strip cards and any other application bestow with the right to make adequate utilisation of the pre-paid payments (Payment Method
Report, 2019). The pre-paid payment instruments in India are categorised as open, closed and semi closed system payment instruments. Any device which is issued by a unit to acquire goods and services only from that unit without cash withdrawals is entitled as closed system payment. So, these instruments restrict its usage for the third party payments or settlement. Whereas, Semi closed system payment instruments are issued for the purpose of buying goods and services, financial services, remittance facilities etc. These instruments are issued by banks (approved by $\mathrm{RBI}$ ) and non banks (authorized by RBI) to a group of identified merchant locations or establishments under a specific contract between the issuer and holder of PPI's through a payment aggregator / payment gateway. Like closed system payment instruments, these instruments also not permitted for cash withdrawals. Open system payment instruments are also issued by banks (approved by RBI) and are utilise at any merchant place to procure any products \& services and transfer of funds. This system permits business correspondents (BC) for cash withdrawal through ATMs at Points of Sale (PoS) terminals. Reserve bank acts in accordance with the permitted legal measure pertaining to issue of pre-paid payment instruments so that users can afford simplified and developed payment pattern in India. Indeed, the consolidated regulatory innovation through various banks, institutional innovation through NPCI and establishment of Aadhaar as a digital identity along with the swift adaptation of smart phones have set the principal basis for fast and sustain growth in payments system in India. Despite, during this COVID 19 pandemic the volume of prepaid cards in certain segments is growing rapidly but its volume seen decline in hospitality \& tourism, airlines, hotels, restaurants along with decrease in cross border payments.

\section{PURPOSE OF THE STUDY}

Presently, the spread of novel coronavirus has become one of the prevalent threats to the economy and financial markets over the globe. Countries across the globe are taking numerous measures to contain the cascading effects of the virus outbreak. In India, the COVID-19 outbreak is also encouraging the use of digital payments. Even the RBI has advocated the customers to use prepaid payment instruments for transactions to ensure contactless transactions. But there are some sectors such as, travelling, theatres, restaurants, entertainment etc. are directly hit by this pandemic and pulled the usage of these payments. Whereas, grocery stores, online gaming, e-learning, online recharges, Ed Techs and utility bills etc., are augmenting the volume of prepaid payments. In nutshell, it seems critical to evaluate the actual volume and value of prepaid payments. Thus, this study is an attempt to comparatively analyse the prepaid payments before COVID-19 and now.

Published By:

Blue Eyes Intelligence Engineering

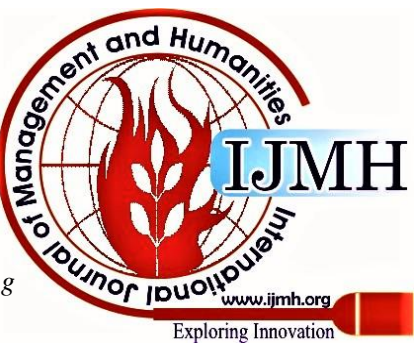

Exploring Innovation
\& Sciences Publication

(C) Copyright: All rights reserved. 


\section{METHODOLOGY}

Data for the study has been collected from secondary sources pertaining to PPI's, its instruments, usage, volume and value. Various reports and e resources have been reviewed and analysed namely, RBI Report (2017 -2019), Payment Method Report (2019), Deloitte Report (2018), Infosys Report (2018), World payment Report (2018), Niti Aayog (Digital Payment Book). The present study compared prepaid payments in terms of volume and value of its instruments (cards, wallets and paper/ gift vouchers etc.) before COVID-19 and now. Before period has considered the demonetisation period and growth has been observed from that period to now (COVID -19 period, 2020) by trend analysis by using the formula:

$$
\frac{\text { Current Year }- \text { Base Year }}{\text { Current Year }} \times 100
$$

\section{FINDINGS AND DISCUSSION} namely, systematically important financial market infrastructure(SIFMIs) and retail payment section. SIFMIs includes financial market clearing (CBLO, forex clearing\& consists of (MICR, Non MICR and CTS) followed by retail electronics clearing (NEFT, IMPS, ECS \& NACH), card payments (credit and debit cards at point of sale terminals) volume swiftly raised over the period of demonetisation (compound average annual growth rate) and then reached at 30.02 percent CAGR (2017-18) and 32.05 percent CAGR (2017-19) respectively. During COVID-19 outbreak, the growth rate of overall payments is arrived at 38.08 percent CAGR which revealed high spike off. PPI transactions in India arose enormously over the years which were mere 30.60 million total annual transactions in the year 2011-12 and arrived at 748.02 million in 2015-16 registering a compounded annual growth rate of $122 \%$. The similar trends were found in the year 2016-17 and 2017-18 with the slight increase in growth rate $124 \%$. In addition, amidst the rising fear of Corona virus, the physical transactions have almost collapsed and people buy all essential goods through digital payments. Due to social distancing measures in lockdown, people have switched to digital payment mode. Even many first-time users who were earlier not very eager about digital payments used this system for buying essentials. Paytm and Google Pay are among the top digital payment apps being used by consumers (Economic Times, 2019). The government of India along with RBI has proposed most upto-dated semi prepaid payment instrument which can be operated only for making retail payments with monthly rechargeable limit of Rs 10000 on 31 $1^{\text {st }}$ December, 2019. This instrument required the mobile number of the user which is verified by one-time password (OTP) to comply with KYC (Know Your Customer) norms and the rechargeable limit should not be increased by Rs. 50,000 per month through its bi- monthly policy namely "Statement on Development and Regulatory Policies". To facilitate its usage the loading and reloading of PPI's permitted to banks
The payment system in India is divided into two segments Government securities) whereas retail payment section and pre-paid instruments (PPI). The overall payments which recorded growth rate of 13 percent CAGR 24 percent CAGR (2016-17), 28 percent CAGR (2017-18),

for bill payments, merchant payments etc. As per Niti Aayog, during COVID 19 pandemic most of the consumers are keen users of Paytm (33 \%) followed by Google Pay (14 $\%)$, PhonePe (4\%), Amazon Pay (10\%), BHIM (6\%) and other apps (33\%). As on May 5, 2020, due to corona virus epidemic, RBI reaffirmed FAQs (Frequently Asked Questions) on cash withdrawals through open system prepaid cards from point of sale (PoS) terminals and debit cards. Further, with the enactment of RBI's operational interoperability guidelines on prepaid payment instrument simplified the digital transaction volume. Prepaid payment instrument includes m-wallets, PPI cards (at point of sale and others) and paper vouchers. The digital payment market had seen significant growth in recent years, specifically in India through PPIs transactions.

Table 1.1 exhibited consistent increase in the volume of total prepaid payments instruments annual transactions from 314 million(2014-15)to748 million(2015-16). Thereafter, the volume has rapidly increased with 1215 million transactions during the demonetisation period (2016-17) represented 62 percent growth over the previous year (201516). Further, PPI volume has shown remarkable increase of 1496million transactions in 2017-18 and 1145 million transactions in 2018-19 and arrived at 8063 million transactions collectively from 2017 to 2019. Despite, during Corona virus pandemic the volume is again augmented in the month of March, 2020 when the lockdown 1.0 has announced in India for social distancing. Subsequently, the volume has shown decrease trend in the month of April and May (lockdown phase II, III and IV) with approximately decrease of 2234 million monthly transactions in both the months. This decrease was due to shut down of travelling, theatres, restaurants, grocery stores, malls etc. Moreover, the usage of PPIs is increased in month of June and showed V shaped recovery, due to unlock 1.0 and 2.0 phase which provided some relaxation to the customers. Overall, there is 88 percent increase in the total volume of PPI transactions from year 2016 to 2020 (till April) which will be further estimated to be mounting over the end of the year 2020 and will reach to approximately 1.3 trillion in 2023. In terms of value of PPI transactions in India for the period 2014-15 to 2019-20, the PPI transactions revealed considerable boost of Rs. 838 billion transactions in 2016-17 which was only of Rs. 213 billion in 2014-15 (Table 1.1). This showed that demonetisation has made momentous growth of 74 percent in the value of PPI transactions (2016-17). In the year 201819 , the value again spiked off with Rs. 2129 billion which was only Rs. 1416 billion in 2017-18, demonstrated 33 percent surge over the previous year. In the subsequent period 2019-20, the value stood at Rs. 15341 billion annual transactions till march 2020 which was again decline in the month of April with Rs. 5693 billion and reached to Rs 9648 billion due to lockdown period. Overall, the value of the PPI's has increased with 97 percent from the demonetisation period (2016 -17) to now (2020).

Published By:

Blue Eyes Intelligence Engineering

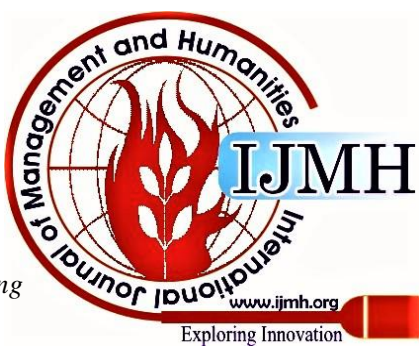


Table 1.1: Total no. (in million) and value (in Rs. Billion) of PPI transactions from the year 2014-15 to 2019-20*

\begin{tabular}{|c|c|c|}
\hline Year & Volume & Value \\
\hline $2014-2015$ & 314 & 213 \\
\hline $2015-2016$ & 748 & 488 \\
\hline $2016-2017$ & 1963 & 838 \\
\hline $2017-2018$ & 3459 & 1416 \\
\hline $2018-2019$ & 4604 & 2129 \\
\hline $2019-2020$ ( March) & 3983 & 15341 \\
\hline April, 2020 & 2086 & 9648 \\
\hline
\end{tabular}

Category wise description of the PPIs volume and value has shown in table 1.2 from the FY 2014-15 to 2019-20. As indicated by the table, the total wallets annual transactions were 604 million in the FY 2015-16 and reached at the level of 4028 million in 2018-19. In terms of value, the wallets grew significantly from Rs. 82 billion (2014-15) to Rs. 520 billion (2016-17). Apparently, m-wallet's market value transactions in India are raised at a CAGR of 211 percent in 2016-17 and arrived at 317 percent in 2018-19 which is likely to achieved approximately Rs. 375 Trillion in 2023. After demonetisation, RBI equipped with several prerequisites for M-Wallet's hassel free transactions by issuing wallets of Rs. 10,000 to Rs. 20,000 and also accepted of Rs. 50,000 per month transactions from wallets to their banks. Thus, from emonetization period to now the increased trend has been observed in wallets transaction's value and volume. Similar trend was observed for prepaid cards where volume of the prepaid card transactions was 209 million in 2016-17 which has turned to 465 million transactions in 2018-19. The value of the cards transactions has elevated in 2019-20 with Rs. 2230 billion transactions (till March, 2020) followed by Rs. 568 billion (2017-18), 282 billion (2016-17) and Rs. 105 billion in (2014-15). This surge was due to coronavirus pandemic which promoted cashless transactions. As far as the other instruments concerned (paper or gift vouchers) there was zero usage during the month of March and April, 2020 and after demonetization period also it reported slow growth. Overall, there is significant increase in the volume and value of prepaid payment through wallets, prepaid cards but low growth for paper vouchers has been observed. Wallets reported maximum usage as compared to prepaid cards and others. However the lockdown slows down the growth prospects but through digital mode enable the steepest month to month increase. In comparison with demonetization period, the volume and value of PPIs increased during COVID 19 period with Google pay, phone pay and wallets. Moreover, when RBI permitted the interoperability of prepaid payments issued in the form of wallets through UPI (Unified payment infrastructure) the Prepaid payments showed high growth. The UPI has demonstrated extensive growth of 197 percent in the total volume with 1236 million transactions of worth Rs. 241 billion until June 28, 2020. Since, the UPI launch in 2016and with the release of UPI 2.0 (P2B) gave another hit to the digital payment system. Even though, in this COVID19 period, UPI is accepted as a most favourable digital payments instrument. Among, the different states in India,
Karnataka is a leading state for the adoption of UPI's followed by Tamil Nadu. Bengaluru city is accounted for the highest number of transaction followed by Chennai, Maharashtra, Pune and Delhi. Furthermore, the inclusion of Bharat Interface for Money (BHIM) app anextension of UPI and USSD, digital payments are easily made digitally. Paytm and Mastercard upsurge with 68 percent and 40 percent growth in 2020 during lockdowns. All this portrayed that now (COVID-19 period) the value and volume of prepaid payments through its instruments (wallets and cards) have increased as compared to emonetization period. It is also estimated that it will be increase with high ratio till the end of the period.

Category wise Total no. (in million) and value (in Rs. Billion) of PPI transactions from the year 2014-15 to 2019-20*

\begin{tabular}{|c|c|c|c|c|c|c|}
\hline \multirow[t]{2}{*}{ Year } & \multicolumn{2}{|c|}{ Wallets } & \multicolumn{2}{|c|}{ Cards } & \multicolumn{2}{|c|}{ Paper Vouchers } \\
\hline & $\begin{array}{c}\text { Vol } \\
\text { ume }\end{array}$ & $\begin{array}{c}\text { Valu } \\
\text { e }\end{array}$ & $\begin{array}{l}\text { Vol } \\
\text { ume }\end{array}$ & $\begin{array}{c}\text { Valu } \\
\text { e }\end{array}$ & Volume & Value \\
\hline 2014- 15 & 255 & 82 & 59 & 105 & $\begin{array}{c}0.5 \\
5\end{array}$ & 26 \\
\hline $2015-16$ & 604 & 206 & 143 & 253 & $\begin{array}{c}0.5 \\
6\end{array}$ & 29 \\
\hline $2016-17$ & $\begin{array}{c}168 \\
7 \\
\end{array}$ & 520 & 209 & 282 & 67 & 36 \\
\hline $2017-18$ & $\begin{array}{c}301 \\
0\end{array}$ & 794 & 347 & 568 & 102 & 54 \\
\hline $2018-19$ & $\begin{array}{c}402 \\
8 \\
\end{array}$ & 1104 & 465 & 886 & 111 & 139 \\
\hline $\begin{array}{l}\text { 2019-20 } \\
\text { (till } \\
\text { March) }\end{array}$ & $\begin{array}{c}317 \\
9\end{array}$ & $\begin{array}{c}1311 \\
1\end{array}$ & 804 & 2230 & - & - \\
\hline April & $\begin{array}{c}184 \\
1 \\
\end{array}$ & 8693 & 245 & 955 & - & - \\
\hline
\end{tabular}

\section{RESEARCH LIMITATIONS}

Although viable efforts have been made to sustain reliability of the study but certain factors cannot be ruled out and are kept in mind when the findings are generalised. The present study is confined to PPI's (including wallets, cards and others) volume and value. Other factors like share occupied by each instrument, market growth, access and availability are still ignored. Further, this is purely secondary based research future research could be executed on primary data to ascertain the people's perceptions regarding prepaid payments.

\section{CONCLUSION}

India has been promptly adapted with new technologies and adopted newer payment channels at a very rapid rate. Demonetization in India has proved a money-spinning prospect for digital payments. The combined efforts of government of India and RBI provided the requisite boost to the usage of electronic payments instruments and the principal beneficiary of this move were prepaid payments instruments. The prepaid payments are flooded with millions of transactions after demonetisation and double the number of users till now.

Published By: 
Key growth driver for PPI's is inter-operability between the pre-paid instrument (PPI) and UPI. Through interoperability with UPI, user's accounts are linked from their bank accounts to different banks to transact with each other in real time. However, the lockdown slows down the growth prospects but through digital mode enable the steepest month to month increase.

In comparison with demonetization period, the volume and value of PPIs increased during COVID 19 period with Google pay, phone pay and wallets. Inspite of growth prospects and robust platforms there should be some implementation to sustain in this outbreak and even after this. No doubt the surge in the UPI transactions, card payments, rise of POS terminals are reducing cash dependency and impetus to set up multiple acquiring touch points in the country. Notwithstanding, there are many customers who still relied on cash due to security reasons, complex system, network unavailability, multiple apps etc. Therefore, it is mandatory to focus on security aspects, provide knowledge and awareness to consumer by organising online webinars and workshops. Further, there should be simplification of procedure for the use of online mode and promotional campaigns should be organiesd for the customers. In addition, India government should invest in the latest technologies to drive innovation, augment competencies, bring customer delight and offer tailor-made solutions

\section{REFERENCES}

1. Bezhovski, Z. (2016). The future of the mobile payment as electronic payment system. European Journal of Business and Management, 8(8), 127-132.

2. Chakravorti, S., \& Lubasi, V. (2006). Payment instruments choice: The case of prepaid cards. Economic Perspective, 30(2), 29-43.

3. Chaubey, D., \& Kumar, P. (2017). Demonetization and its impact on adoption of digital payment: Opportunities, issues and challenges. Abhinav National Journal of Research in Commerce \& Management, 6(3), 1-14

4. Deloitte Report (2017). Leading the cashless charge -Evolution of the digital wallet industry in India. Retrieved from https://www2.deloitte.com/content/dam/Deloitte/in/Documents/strate gy/in-strategy-l. Last Visited 16-06-2020.

5. Dennis, A. (2004). Electronic payment systems: A user-centered perspective and interaction design, Netherlands: Technische Universiteit Eindhoven.

6. Department of Payment and Settlement Systems, Reserve Bank of India (2018): Payment systems in India: Vision 2018. Retrieved from https://www.businesstoday.in/sectors/banks/rbi-launches-newprepaid-payment- instrument-ppi-digita. Last visited 20-06-2020.

7. Global Payment Report (2019). Amid sustained growth, accelerating challenges demand bold actions. Retrieved from https://www.indiatoday.in/magazine/the-big-story/story/20200323-aneconomic-coronary-1654645-2020. Last Retrieved on 21-06-2020.

8. Infosys Report (2020). Prepaid card industry- Product offering, leading players, current trends and challenges faced. Retrieved from filings/annualreport/annual/documents/infosys-ar-20.pdf. Last visited 18-06-20

9. Kaur, k., \& Pathak. A. (2015). E-payment system on E-commerce in India. International Journal of Engineering Research and applications, 5(2), 79-87.

10. NITI Aayog (2018). Digital Payments: Trends, issues, and opportunities. Retrieved from https://www.questia.com/library/journal/1G1-221274545/paymentinstrument-choice-th. Last Visited 20-06-2020.

11. RBI Report (2017). Master direction on issuance and operation of prepaid payment instruments. Retrieved from https://rbi.org.in/Scripts/BS ViewMasDirections.aspx?id=11142, 2017.Last visited 16-06-2020.

12. RBI Report (2018). Payment and settlement systems in india: Vision2018. Retrieved from https://www.rbi.org.in/scripts/ Publication Vision Documents.aspx?Id=842, 2018. Last visited 16-06-2020.
13. RBI Report (2020). RBI bulletin. Retrieved from Reserve Bank of India: https://www.rbi.org.in/scripts/BS_ViewBulletin.aspx. Last visited 18-06-2020.

14. Roy, S., \& Sinha, I. (2014). Determinants of customers' acceptance of electronic payment system in Indian banking sector - A study. International Journal of Scientific \& Engineering Research, 5 (1), 177-187

15. Sarkar, S. (2017). Prepaid payment instruments in India- A journey towards a digital economy. Retrieved from https://en.wikipedia.org/wiki/Prepaid_Pay. Last visited 19-06-2020

16. Shah, Z. A. (2017). Digital payment system: Problems and prospects. International Journal of Economic and Business Review, 5(8), 194201.

17. Shaikh, A. A., Hanafizadeh, P., \& Karjaluoto, H. (2017). Mobile banking and payment system: A conceptual standpoint. International Journal of E-Business Research, 13(2), 14-27.

18. Slozko, O., \& Pello, A. (2015). Problems and risks of digita technologies introduction into E-payments. Transformations in Business and Economics, 14(1), 42-59.

19. https://www.bankingtech.com/files/2014/03/PPICC280314_A.pdf.Ac cessed 15.05.2020

20. https://docplayer.net/50471991-Message-d-s-rawat-d-s-rawatsecretary-general-secretary-general.html. Accessed on 19-06-2020

21. https://www.bankingtech.com/files/2014/03/PPICC280314_A.pdf. Accessed on 20-06-2020

22. https://www.bankingtech.com/files/2014/03/PPICC280314_A.pdf. Accessed on 20-06-2020

23. https://en.wikipedia.org/wiki/Prepaid_Payment_Instruments_in_India Accessed on 20-06-2020

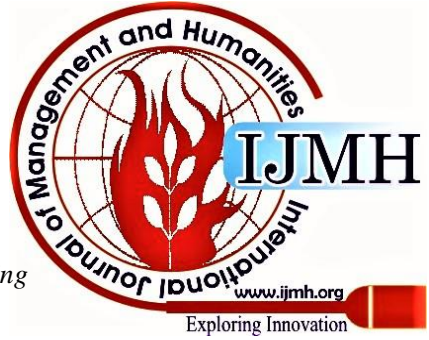

